\title{
The Effect of Pastoral Counseling on the Psycho-Spiritual Well-Being of Seminarians
}

\author{
${ }^{1}$ Rev. Fr. Eugene D. Lucerna \\ ${ }^{2}$ Lisa Anna M. Gayoles \\ ${ }^{1}$ Kabankalan Catholic College, Negros Occidental, Philippines \\ ${ }^{2}$ University of Negros Occidental-Recoletos, Bacolod City, Philippines \\ lisagayoles@yahoo.com
}

\begin{abstract}
This study aimed to determine the effect of pastoral counseling on the psycho-spiritual well-being of the seminarians. It utilized the pretestposttest control group experimental design. Thirty-two seminarians participated in the study. The seminarians were randomly assigned to the experimental group and the control group, with 14 participants and 18 participants, respectively. The saliva $\mathrm{pH}$ strips and the Psychological General Well-Being Index (PGWBI) were used to measure the psychological well-being, while the Spiritual Well-Being Questionnaire (SWBQ) was used to measure spiritual well-being. The results of the study revealed that there was a significant difference in psycho-spiritual well-being between the experimental group and the control group after the strategic pastoral counseling. The findings suggest implications in strategic pastoral counseling as an effective program for the improvement and sustainability of the psycho-spiritual well-being of the seminarians.
\end{abstract}

Keywords: Seminarians, Pastoral Counseling, Psychological Well-Being, Spiritual Well-Being

Date Submitted: November 27, 2018

Date Revised: January 17, 2019 


\subsection{Introduction}

The vocation to the priesthood in the Catholic Church is a call from God and a new identity (McShane, 2015). Being a priest is not something that comes automatically, but it is the product of a long process of formation. The training of those who aspire to become priests is different from the preparation of the lay persons who are baptized into the Church with secular quality (Avivor, 2009). Candidates must possess a liberal education, professional knowledge, and must acquire the behavior, values, and beliefs becoming of this calling (Duc Dao, 2015). The seminary has been instituted in the Catholic Church for the formation of candidates for the priesthood with the purpose to teach these candidates what they ought to know to become future priests and bishops (Duc Dao, 2015; O'Connell, 2014; Knight, 2012).

Seminary formation is a form of professional socialization that attends to all aspects of the seminarians' lives, including their emotional maturity, carnal thoughts, senses, perceptions, and behaviors, a gradual purification of the mind (Keating, 2010; Stanosz, 2004). Candidates to the priesthood must appreciate particularly the vision of a formation, which should be complete and integral, embracing the human, spiritual, intellectual and pastoral areas (Duc Dao, 2015).

Seminarians seem to be vulnerable to psychosocial issues despite the sacredness of their calling to serve the Catholic Church. There is a continuing concern regarding the integrity of the psycho-spiritual well-being of the Catholic seminarians as future leaders of the Catholic Church, following the abuses perpetrated by some ordained Catholic priests. Psycho-spiritual well-being refers to a person's experiences and the effects these experiences have on him (Bash, 2004). The psychological dimension is the conduit through which spiritual well-being is expressed (Manning-Walsh, 2005). In addition to focusing on the problems and coping strategies of seminarians as predictors of commitment to the priestly vocation, it is essential to deal with the psychological as well as the spiritual well-being of the seminarians prior to sending them out from seminary formation (Gañon et al., 2008).

Pastoral counseling is a form of counseling that integrates pastoral theology and secular psychology in providing a holistic approach to psychotherapy, where faith, theology, and psychology play foundational roles (Dayringer, 2012; Cooper-White, 2004; Kehe, 1997). Pastoral counseling is spiritual in nature and practical in focus (Karner, 2013). It focuses on bringing a person into proper relational alignment with God, with others, and/or with themselves. On the contrary, a person's counseling becomes pastoral when the counselee or the counselor focuses the relationship upon the relation of God to the process of their lives (Karner, 2013).

The present study deals with counseling psychology, which focuses on facilitating personal and interpersonal functioning across the lifespan (Society of Counseling Psychology, 2017). It involves practices that help individuals enhance their well-being, lessen distress, minimize maladjustment, manage crises, and assist them to function better. Through pastoral counseling, counselors and psychologists, as well as the seminary educators or formators may be able to offer seminarians a safe and secure place to express their anxieties, fears, frustrations, trauma, grief, or sadness. The researcher believes that pastoral counseling plays an important role in the integral 
formation of seminarians as well as improving and sustaining their psycho-spiritual well-being.

The purpose of the study was to determine the effect of pastoral counseling on the psycho-spiritual well-being of the seminarians. It was hypothesized that demographic characteristics influence the psycho-spiritual well-being of the seminarians at baseline; the psychological well-being correlate with the spiritual well-being of the seminarians at baseline; and pastoral counseling affects the psycho-spiritual well-being of the seminarians.

\subsection{Theoretical Considerations}

The emerging adulthood theory and the biopsychosocial model provided the framework for determining the effect of pastoral counseling on the psycho-spiritual well-being of the seminarians.

According to Jeffrey Arnett, a psychologist and proponent of the emerging adulthood theory, emerging adulthood occurs between the end of puberty and the threshold of adulthood. The focus is on the 18-29-year-old population, which includes both senior high school and college students. During emerging adulthood, identity explorations transform from the temporary and brief explorations of an adolescent to the more serious and focused commitments of a late emerging adult (Trible, 2015; Reifman, Arnett \& Colwell, 2007).

According to the biopsychosocial model, wellness and illness result from the interaction of the biological, psychological and social factors. Influences on behavior include demographic factors such as age, sex, culture, socio-economic; social and environmental factors such as access to care and societal attitudes to illness and treatment; and personal factors such as personality, emotions, and cognitions (Arnibal, 2014).

Priestly formation in the seminary is like a world set apart, but may not be the best way of preparing young men for working in the world, especially if these men have been set apart at a young age (Pring, 2014). The whole community of seminary personnel plays an active role in the priestly formation of seminarians (CBCP, 2006).

Adolescence is a period of biological changes such as the functioning of some hormones (Yeager, 2017) and psychosocial changes such as self-esteem, self-concept, personality, and social skills (Ebrahimisani, Hashemian \& Dvkanha, 2012). The transition from adolescence to early adulthood is a time of active identity development. Career aspirations play an essential role in shaping adult identities and wellbeing (Ashby \& Schoon, 2012). Emerging adulthood ends with making lifelong decisions, resulting in a self-conception of feeling like an adult (Trible, 2015).

Like any other student, seminarians are likely to be confronted with the same social, personal, and academic issues. Seminarians' needs should be identified before designing or modifying counseling services and programs (Adubale \& Aluede, 2017).

Psychological well-being is the combination of feeling good and functioning effectively (Huppert, 2009). Exposure to stressors activates the hypothalamic-pituitaryadrenal (HPA) axis, as evidenced by increased secretion of the stress hormone cortisol (Thompson, 2014; Huppert, 2009). Both positive and negative states are associated with the cortisol response (Huppert, 2009). 
According to Stawski, Cichy, Piazza, and Almeida (2013) naturally occurring daily stressors influence salivary cortisol. Cortisol was significantly higher on stressor days than on stressor-free days, especially during arguments and overloads at home. An inverse correlation between $\mathrm{pH}$ and anxiety exists such that as stress and anxiety increase, saliva and urine $\mathrm{pH}$ decrease (Gayoles, 2010).

Spiritual well-being is a measure of how good one feels about oneself and how well one relates to important aspects in the world. It has been identified as fundamental to overall health and well-being and has a positive influence on individual health (Awazie, Osarenren \& Nwadinigwe, 2015). Psychological and spiritual coping strengthens the relationship between spirituality and well-being, especially during stress (Awazie et al., 2015).

Pastoral counseling is the integration of psychological theories and methods of counseling with religion, theology, and concepts of spirituality (Streets, 2014). The goals of pastoral counseling are spiritual growth, problem resolution, and restoration of psychological health (Sperry, 2016). The strategic pastoral counseling model is brief and time-limited, holistic, structured, homework-based, church-based, spiritually focused, and explicitly Christian (Benner, 2003).

Diversity is a significant benefit working in groups (APA, 2017). Groups are an effective method for delivering psychological interventions with diverse populations. Group counseling interventions used in schools are successful at associating personalsocial skills such as social skills and academic development like increased test scores or grades (Steen, Henfield, \& Booker, 2014).

Several types of researches were conducted on the psycho-spiritual well-being and its link to selected demographic characteristics. Nassar, Hiraishi, Islam, Otsuki, and Tagami, (2014) conducted a study to detect age-related changes in salivary biomarker, and their results indicated that there is no statistically significant difference in the saliva $\mathrm{pH}$ between the younger and older groups. This implies that saliva components can increase, decrease, or remain stable with age. De Campos et al. (2015) conducted a pilot study to assess salivary characteristics of normal-weight, overweight, and obese children and found that age, household income, parents' education, saliva flow and pH do not differ among groups. In a study of hearing impaired adolescents by Mohanraj and Selvaraj (2013), there is a significant positive correlation among variables age, sex, academic self-efficacy, and spirituality, and psychological well-being.

Kibret and Tareke (2017) showed that the batch year of students has no significant relationship to psychological well-being measures, while sex and income are significantly correlated with almost all the psychological well-being measures. Afrisham (2016) evaluated the levels of salivary IgA under psychological stress and its relationship with rumination in medical students. Results showed significance in the levels of salivary IgA of medical students under psychological stress. Due to exam stress, salivary IgA dropped.

Ziapour, Khatony, Jafari, and Kianipour (2017) found that there are significant correlations among the demographic variables gender, marital status, age, housing, academic term, and field of study and spiritual well-being. Alorani and Alradaydeh (2017) identified the relationship between depression, aggression, and spiritual well-being 
among the university students. Results of their study showed a negative correlation between spiritual well-being and both of depression and aggression. Additionally, the differences in the mean scores of spiritual well-being based on students' educational year were not significantly different.

Roe et al. (2013) and Thompson et al. (2012) identified a link between different levels of exposure to green space and improved physiological stress as measured by diurnal patterns of cortisol secretion. Both had similar results indicating that residing within areas of greater percentage green space is associated with lower stress.

Nepomuceno, Cardoso, Ximenes, Barros, and Leite (2015) and Yeresyan and Lohaus (2013) investigated the relationship between mental health and well-being in urban and rural areas. Nepomuceno et al. (2015) found significant differences in the psychological well-being between the inhabitants of the rural and urban communities, with a higher average well-being score in the rural area, while the urban sample had a higher average regarding the prevalence of common mental disorders. Yeresyan and Lohaus (2013) found that adolescents who live in rural parts experience more stress than their urban counterparts in both Turkey and Germany.

According to Wissing, Temane, Khumalo, Kruger, and Vorster (2013), urbanization has an impact on psychosocial well-being. They showed that the rural group manifested higher levels of well-being on spiritual well-being, although rural group manifested relatively higher levels of symptoms of distress than the urban group.

Kibret and Tareke (2017) found out that female students and those from lower family income group are more vulnerable than their counterparts. Stein et al. (2013) suggested a direct relationship between perceived economic pressure and psychological well-being such that young adults in financial crisis reported higher levels of depressed mood and anxiety. Powell-Young (2012) found that socioeconomic level appears to be the most significant predictors of self-rated health while Vahedi and Nazari (2012) discovered that family income level is associated positively with spiritual well-being and life satisfaction.

Johnson and Gans (2016) revealed that children's depressed and anxious behavior are related to their parents' individual cortisol response to family interaction. Davids, Ryan, Yassin, Hendrickse, and Roman (2016) suggested that intact families predict higher satisfaction of basic psychological needs among adolescents than do non-intact families. Likewise, Akwei (2015) revealed that adolescents from a functional family have high psychological well-being and that parental conflict and adolescent psychological well-being are negatively correlated. Petts (2014) found that parental interaction and religious services attendance with parent/s in late childhood are related to higher psychological well-being; whereas, parental conflict in a nontraditional family is associated with lower well-being among youth.

Wang (2014) investigated the relationship between parental autonomy support and emerging adult depression and anxiety over time and found no significant relationship between parental autonomy support and emerging adult depression and anxiety symptoms over time with family financial support having a moderating effect. Lucas-Thompson (2013) examined how the quality of relationships with parents, as well as life stress, is associated with cortisol production across the day among emerging adults and indicated that emerging adults with more warmth in maternal relationships 
produce less total cortisol. Wiggins (2013) found out that there is no statistically significant effect of maternal relationship cohesion on the spiritual well-being of daughters.

Okonkwo (2015) found that there is a positive relationship between servant leadership and socio-moral climate as well as a direct positive relationship between servant leadership and spiritual well-being. Socio-moral climate, which moderates the relationship between servant leadership and spiritual well-being, is higher when sociomoral climate is evaluated positively.

The following researchers studied the relationship between psychological wellbeing and spiritual well-being. Maryam Mosavi, Pourmarzi, Dehganzadeh, Ruzbehan and Pourhamed (2015) indicated that there is no relationship between serum cortisol level in morning and spiritual well-being scale in nursing students. However, Mihaljević, S. et al. (2011) showed that there is a significant relationship between spiritual wellbeing and cortisol levels of veterans suffering from PTSD. Fabbris, Mesquita, Caldeira, Carvalho, and Carvalho (2016) indicated that there is a significant negative relationship between anxiety and spiritual well-being, thus, when experiencing anxiety, spiritual well-being is low. Unterrainer, Lewis, and Fink (2012) implied a positive relationship between religiosity/spirituality and a variety of indicators of mental health, including subjective well-being and personality dimensions.

The following researchers investigated the effect of counseling on psychospiritual well-being. Muse, Love, and Christensen (2016) revealed that a week-long multi-therapist intensive outpatient intervention significantly improves depression, emotional exhaustion, and depersonalization of clergy suffering from depression and burnout. This implies that a week-long multi-therapist intensive outpatient intervention is useful in reducing depression and burnout. Aboulafia-Brakha, Suchecki, GouveiaPaulino, Nitrini, and Ptak (2014) found that there is a significant reduction in the salivary cortisol level between the caregivers of Alzheimer's patients who received CBT and those who received psychoeducation. This implies that CBT lowers psychophysiological responses to stressful situations by reducing diurnal cortisol levels. Jafari et al. (2013) showed that a 6-week spirituality-based intervention significantly improves the spiritual well-being and quality of life of Iranian women with breast cancer. Bhogaonker (2012) suggested that a yoga-based meditation program might be effective in reducing negative psychological states and enhancing quality of life for homeless adults experiencing significant distress.

The result of this study would give the community responsible for the integral formation of seminarians a clear perspective on the psycho-spiritual needs of seminarians and gain insights on the importance of pastoral counseling in the promotion of the psycho-spiritual well-being of their seminarians. Mental health professionals would benefit through developing pastoral counseling programs specific to the psychosocial needs of seminarians and priests. This study would also serve as a reference for future researchers, especially on the efficacy of different counseling programs on the wellbeing of seminarians as well as of priests. 


\subsection{Materials and Method}

Experimental research allows the researcher to identify causal relationships (Odle \& Mayer, 2009; Ardales, 2008). An essential feature of the experimental research design is the deliberate manipulation of the independent variable, which will affect events under investigation. It controls the influence of confounding extraneous variables through randomization.

This study aimed to determine the effect of pastoral counseling on the psychospiritual well-being of seminarians. The researcher employed the pretest-posttest control group experimental design (Odle \& Mayer, 2009; Ardales, 2008). It is an excellent research design because it includes a control group and an experimental group, and it has random assignment of participants to these comparison groups.

The two groups received pretest measurements for psycho-spiritual well-being to determine the differences between the two groups at baseline and to serve as a basis in determining the effect of pastoral counseling. After counseling, the two groups received posttest measurements for psycho-spiritual well-being. Pastoral counseling was expected to indicate a change in the experimental group and not in the control group.

The participants of the study were the seminarians officially enrolled at the Sacred Heart Seminary School of Philosophy in the city of Bacolod for the Second Semester of Formation Year 2017 - 2018. There was a total of 36 seminarians from Preparatory Class to the 4th Year Philosophy. They were randomly assigned to the experimental group and the control group, with 18 participants in each group. All participants had pretest measurements for psycho-spiritual well-being taken at baseline. Only the experimental group received pastoral counseling. For the posttest measurements for the experimental group, only 14 participants were included. Attrition was due to absences, pastoral duties, and other personal matters. Posttest measurements were taken from all the participants in the control group.

To measure psychological well-being, the saliva $\mathrm{pH}$ strips and the Psychological General Well-Being Index (PGWBI) were used by the researcher. The saliva $\mathrm{pH}$ strips have a range of 4.5 to 9.0 with $0.25 \mathrm{pH}$ unit increments from 5.75 to 7.5 (Gayoles, 2005). A reading of less than or equal to 6.75 indicates ill-being while a reading of 7.0 to 7.25 indicates well-being (Gayoles, 2010; Huppert, 2009). Pretest measurements of the participants were obtained during the orientation while posttest measurements were obtained after the intervention of pastoral counseling. The PGWBI targets peoples' selfrepresentations of an aspect of their general well-being (Dupuy, 2002). There are 22 items, with six dimensions: Anxiety, Depressed Mood, Positive Well-being, Self-Control, General Health, and Vitality. For each dimension, score is given by the sum of the relevant items. The PGWBI generates an overall index or total score for general wellbeing, which ranges from 0 (poor quality of life) to 110 (good quality of life) (Dupuy, 2002). Participants completed the PGWBI twice, during the orientation and after the intervention of pastoral counseling.

To measure spiritual well-being, the Spiritual Well-Being Questionnaire (SWBQ) was used by the researcher. There are 20 items with four domains: personal, communal, environmental, and transcendental (Gomez \& Fisher, 2003). Raw scores were used and 
were obtained by calculating the sum of items (Moodley, 2008). A 5-point Likert scale was used for the items: 1 = Very Low to 5 = Very High (Holder, Coleman, \& Wallace, 2010). Participants completed the SWBQ twice, during the orientation and after the intervention of pastoral counseling.

The researcher, with the approval of the Rector of Sacred Heart Seminary School of Philosophy in the city of Bacolod, conducted an experimental research to determine the effect of pastoral counseling on the psycho-spiritual well-being of the seminarians. The researcher personally gathered the pretest measurements at baseline and the posttest measurements after the intervention of pastoral counseling for the psycho-spiritual well-being of the seminarians.

The pastoral counseling was based on the Benner's Strategic Pastoral Counseling Model (Benner, 2003). It is brief and time-limited, structured, and homework-based. It involved three 90-minute sessions. The goals of the initial session were to know the seminarians and establish the goals for the pastoral counseling. The second session aimed to explore of the seminarians' thoughts, feelings, and behavior associated with their central concern and to aid in developing new coping strategies. For the concluding session, the seminarians developed an action plan to address their unique needs and goals. A registered psychologist conducted the three sessions and was facilitated by the researcher.

Data gathered were analyzed utilizing the appropriate statistical tool. To determine the psycho-spiritual well-being, the mean was utilized. Psychological wellbeing was categorized as optimal well-being, slight well-being, and ill-being using the saliva $\mathrm{pH}$ strips, while categorized as positive well-being, moderate distress, and severe distress using the PGWBI. Spiritual well-being was categorized as very high, high, moderate, low, and very low. To determine the significance, the relationships among the demographic characteristics and the psycho-spiritual well-being of the seminarians and the significance of the relationship between the psychological well-being and the spiritual well-being of the seminarians, Pearson-Product Moment Coefficient of Correlation $r$ and Fisher's Exact Test were utilized. To determine the significance of the difference between the psycho-spiritual well-being of the experimental group and the control group before and after the intervention, the independent $t$-test, Welch's $t$-test and the dependent $t$-test were used. The effect size was also computed to identify practical significance

\subsection{Results}

Saliva pH of the seminarians at baseline. As a whole $(M=6.99, S D=0.15)$, the saliva $\mathrm{pH}$ of the seminarians indicated "slight well-being." When they were grouped according to the demographic characteristics namely, age, year level, location of residence, economic status, family structure, parenting style, and relationship with formators, the saliva $\mathrm{pH}$ of the seminarians indicated "slight well-being." 
Table 1. Saliva pH of the Seminarians at Baseline

\begin{tabular}{|c|c|c|c|}
\hline & $M$ & $S D$ & Interpretation \\
\hline As a whole $(N=36)$ & 6.99 & 0.15 & Slight Well-being \\
\hline \multicolumn{4}{|l|}{ Age } \\
\hline Younger $(n=23)$ & 7.00 & 0.13 & Slight Well-being \\
\hline Older $(n=13)$ & 6.98 & 0.19 & Slight Well-being \\
\hline \multicolumn{4}{|l|}{ Year Level } \\
\hline Preparatory Class $(n=5)$ & 6.95 & 0.21 & Slight Well-being \\
\hline First Year Philosophy $(n=8)$ & 7.03 & 0.16 & Slight Well-being \\
\hline Second Year Philosophy $(n=9)$ & 7.00 & 0.13 & Slight Well-being \\
\hline Third Year Philosophy $(n=10)$ & 6.95 & 0.16 & Slight Well-being \\
\hline Fourth Year Philosophy $(n=4)$ & 7.06 & 0.13 & Slight Well-being \\
\hline \multicolumn{4}{|l|}{ Location of Residence } \\
\hline Urban $(n=23)$ & 7.00 & 0.15 & Slight Well-being \\
\hline Rural ( $n=13)$ & 6.98 & 0.16 & Slight Well-being \\
\hline \multicolumn{4}{|l|}{ Economic Status } \\
\hline Poor $(n=18)$ & 6.97 & 0.17 & Slight Well-being \\
\hline Low Income $(n=10)$ & 6.98 & 0.14 & Slight Well-being \\
\hline Lower Middle to Middle Income ( $n=8$ ) & 7.06 & 0.11 & Slight Well-being \\
\hline \multicolumn{4}{|l|}{ Family Structure } \\
\hline Intact $(n=28)$ & 7.00 & 0.17 & Slight Well-being \\
\hline Non-Intact $(n=8)$ & 6.97 & 0.09 & Slight Well-being \\
\hline \multicolumn{4}{|l|}{ Parenting Style } \\
\hline Parental Care $(n=24)$ & 6.99 & 0.17 & Slight Well-being \\
\hline Parental Overprotection ( $n=3$ ) & 7.08 & 0.14 & Slight Well-being \\
\hline Parental Autonomy $(\mathbf{n}=9)$ & 6.97 & 0.08 & Slight Well-being \\
\hline \multicolumn{4}{|l|}{ Relationship with Formators } \\
\hline Good $(n=30)$ & 7.0 & 0.16 & Slight Well-being \\
\hline Poor/Tensed $(n=6)$ & 6.96 & 0.10 & Slight Well-being \\
\hline
\end{tabular}

Psychological well-being of seminarians at baseline. Altogether $(M=66.83$, SD = 14.91), the seminarians were "moderately distressed." When they were grouped according to the demographic characteristics, namely age, year level, location of residence, economic status, family structure, parenting style, and relationship with formators, seminarians were "moderately distressed," with the exception of the older group ( $M=6.98, S D=0.19)$, who had "positive well-being," and the first year $(M=7.03$, $\mathrm{SD}=0.16)$ and those with poor/tensed $(\mathrm{M}=6.96, \mathrm{SD}=0.10)$ relationship, who were "severely distressed." 
Table 2. Psychological Well-being of the Seminarians at Baseline

\begin{tabular}{|c|c|c|c|}
\hline & $M$ & $S D$ & Interpretation \\
\hline As a whole $(N=36)$ & 66.83 & 14.91 & Moderate Distress \\
\hline \multicolumn{4}{|l|}{ Age } \\
\hline Younger $(n=23)$ & 63.04 & 12.47 & Moderate Distress \\
\hline Older $(n=13)$ & 73.54 & 16.93 & Positive Well-being \\
\hline \multicolumn{4}{|l|}{ Year Level } \\
\hline Preparatory Class $(n=5)$ & 66.0 & 16.19 & Moderate Distress \\
\hline First Year Philosophy $(n=8)$ & 58.75 & 13.60 & Severe Distress \\
\hline Second Year Philosophy $(n=9)$ & 71.11 & 13.51 & Moderate Distress \\
\hline Third Year Philosophy $(n=10)$ & 68.2 & 17.00 & Moderate Distress \\
\hline Fourth Year Philosophy $(n=4)$ & 71.0 & 14.02 & Moderate Distress \\
\hline \multicolumn{4}{|l|}{ Location of Residence } \\
\hline Urban $(n=23)$ & 65.96 & 15.06 & Moderate Distress \\
\hline Rural ( $n=13)$ & 68.38 & 15.10 & Moderate Distress \\
\hline \multicolumn{4}{|l|}{ Economic Status } \\
\hline Poor $(n=18)$ & 67.0 & 17.72 & Moderate Distress \\
\hline Low Income $(n=10)$ & 67.2 & 10.34 & Moderate Distress \\
\hline Lower Middle to Middle Income $(n=8)$ & 66.0 & 14.50 & Moderate Distress \\
\hline \multicolumn{4}{|l|}{ Family Structure } \\
\hline Intact $(n=28)$ & 68.46 & 14.61 & Moderate Distress \\
\hline Non-Intact $(n=8)$ & 61.13 & 15.47 & Moderate Distress \\
\hline \multicolumn{4}{|l|}{ Parenting Style } \\
\hline Parental Care $(n=24)$ & 68.38 & 15.81 & Moderate Distress \\
\hline Parental Overprotection $(n=3)$ & 63.0 & 10.82 & Moderate Distress \\
\hline Parental Autonomy $(n=9)$ & 64.0 & 14.24 & Moderate Distress \\
\hline \multicolumn{4}{|l|}{ Relationship with Formators } \\
\hline Good $(n=30)$ & 68.7 & 15.40 & Moderate Distress \\
\hline Poor $/$ Tensed $(n=6)$ & 57.5 & 7.40 & Severe Distress \\
\hline
\end{tabular}

Spiritual well-being of seminarians at baseline. As a group $(M=82.97, S D$ $=10.48$ ), the spiritual well-being of the seminarians was "high." When they were grouped according to the demographic characteristics, namely age, year level, location of residence, economic status, family structure, parenting style, and relationship with formators, seminarians had "high" spiritual well-being with exception of the second year $(M=88.56, S D=12.38)$ who had "very high" spiritual well-being.

Relationships among the demographic characteristics and the saliva $\mathrm{pH}$ of the seminarians. There were no significant relationships among the demographic characteristics and the saliva $\mathrm{pH}$ of the seminarians at baseline, namely: age $(r=-.21, p=$ $.23)$, year level $(p=.83)$, location of residence $(p=1.00)$, economic status $(p=.59)$, family structure $(p=.38)$, parenting style $(p=.35)$, and relationship with formators $(p=.81)$. 
Table 3. Spiritual Well-being of the Seminarians at Baseline

\begin{tabular}{|c|c|c|c|}
\hline & $M$ & $S D$ & Interpretation \\
\hline As a whole $(N=36)$ & 82.97 & 10.48 & High \\
\hline \multicolumn{4}{|l|}{ Age } \\
\hline Younger ( $n=23$ ) & 81.43 & 11.18 & High \\
\hline Older $(n=13)$ & 85.69 & 8.86 & High \\
\hline \multicolumn{4}{|l|}{ Year Level } \\
\hline Preparatory Class $(n=5)$ & 84.2 & 9.58 & High \\
\hline First Year Philosophy $(n=8)$ & 77.0 & 11.0 & High \\
\hline Second Year Philosophy $(n=9)$ & 88.56 & 12.38 & Very High \\
\hline Third Year Philosophy $(n=10)$ & 81.1 & 7.75 & High \\
\hline Fourth Year Philosophy $(n=4)$ & 85.5 & 8.70 & High \\
\hline \multicolumn{4}{|l|}{ Location of Residence } \\
\hline Urban $(n=23)$ & 82.43 & 10.03 & High \\
\hline Rural ( $n=13)$ & 83.92 & 11.59 & High \\
\hline \multicolumn{4}{|l|}{ Economic Status } \\
\hline Poor $(n=18)$ & 82.33 & 11.38 & High \\
\hline Low Income $(n=10)$ & 81.5 & 9.34 & High \\
\hline Lower Middle to Middle Income $(n=8)$ & 86.25 & 10.31 & High \\
\hline \multicolumn{4}{|l|}{ Family Structure } \\
\hline Intact $(n=28)$ & 84.57 & 9.32 & High \\
\hline Non-Intact $(n=8)$ & 77.38 & 12.95 & High \\
\hline \multicolumn{4}{|l|}{ Parenting Style } \\
\hline Parental Care $(n=24)$ & 82.96 & 11.02 & High \\
\hline Parental Overprotection ( $n=3$ ) & 85.0 & 6.56 & High \\
\hline $\begin{array}{l}\text { Parental Independence/Autonomy ( } \mathrm{n}= \\
\text { 9) }\end{array}$ & 82.33 & 10.87 & High \\
\hline \multicolumn{4}{|l|}{ Relationship with Formators } \\
\hline Good $(n=30)$ & 82.73 & 11.18 & High \\
\hline Poor $/$ Tensed $(n=6)$ & 84.17 & 6.49 & High \\
\hline
\end{tabular}

Relationships among the demographic characteristics and the psychological well-being of the seminarians. There were no significant relationships among the demographic characteristics and the psychological well-being of the seminarians at baseline, namely: year level $(p=.09)$, location of residence $(p=.82)$, economic status $(p=.51)$, family structure $(p=.27)$, parenting style $(p=.20)$, and relationship with formators $(p=.07)$, with the exception between age and the psychological well-being of the seminarians $(r=.34, p=.04)$ where a significant relationship existed.

Relationships among the demographic characteristics and the spiritual well-being of the seminarians. There were no significant relationships among the demographic characteristics and the spiritual well-being of the seminarians at baseline, namely: age $(r=.17, p=.34)$, year level $(p=.79)$, location of residence $(p=1.00)$, family 
structure $(p=.09)$, parenting style $(p=.95)$, and relationship with formators $(p=.62)$, with the exception between economic status and the spiritual well-being $(p=.04)$ of the seminarians where a significant relationship existed.

Relationships the psychological well-being and the spiritual well-being of the seminarians. There was no significant relationship between the saliva $\mathrm{pH}$ and the spiritual well-being of the seminarians $(r=.21, p=.21)$, while there was a significant relationship between the psychological well-being and the spiritual well-being of the seminarians $(r=.41, p=.01)$.

Difference between the psycho-spiritual well-being of the experimental group and the control group before and after the intervention. There was no significant difference in the saliva $\mathrm{pH}$ between the experimental group and the control group at baseline $[t(34)=-0.27, p=.79]$. However, there was a statistical difference between their saliva $\mathrm{pH}$ after the pastoral counseling $[t(29)=8.48, p<.0001, \mathrm{Cl} .95$ $0.34,0.56]$. Further, Cohen's effect size value $(d=2.97)$ suggests a very high practical significance. Results showed that there was a significant difference in the saliva $\mathrm{pH}$ of the experimental group before and after pastoral counseling $[t(13)=-2.46, p=.03]$ and a significant difference in the saliva $\mathrm{pH}$ of the control group before and after pastoral counseling $[t(17)=6.02, p<.0001]$.

Difference in the psychological well-being between the experimental group and the control group at baseline. There was no significant difference in the psychological well-being between the experimental group and the control group at baseline $[t(34)=-1.58, p=.12]$. However, there was a statistical difference between their psychological well-being after the pastoral counseling $[t(24)=1.44, p=.16, \mathrm{Cl} .95$ $-2.98,16.87]$. Further, Cohen's effect size value $(d=0.52)$ suggests a moderate practical significance. Results showed that there was a significant difference in the psychological well-being of the experimental group before and after pastoral counseling $[t(13)=-3.68$, $p<.01]$ while there was no significant difference in the psychological well-being of the control group before and after pastoral counseling $[t(17)=0.68, p=.51]$.

Difference in the spiritual well-being between the experimental group and the control group at baseline. There was no significant difference in the spiritual wellbeing between the experimental group and the control group at baseline $[t(34)=-1.61$, $p=.12]$. However, there was a statistical difference between their spiritual well-being after the pastoral counseling $[t(27)=1.64, p=.11, \mathrm{Cl} .95-1.51,13.54]$. Further, Cohen's effect size value $(d=0.40)$ suggests a moderate practical significance. Result showed that there was a significant difference in the spiritual well-being of the experimental group before and after pastoral counseling $[t(13)=-4.17, p<.01]$. Conversely, there was a significant difference in the spiritual well-being of the control group before and after the intervention $[t(17)=1.72, p=.10]$. 


\subsection{Discussion}

Cortisol is significantly higher on stressor days than on stressor-free days, especially during arguments and overloads at home (Stawski, Cichy, Piazza, \& Almeida, 2013). Biomarker and self-reported measures of stress are linked to health-related consequences (Van Gaasbeck et al., 2017).

According to Nassar et al. (2014), salivary biomarker and glutathione: oxidized glutathione ratio (GSH:GSSG ratio) can be an indicator of aging. The results of their study indicated that the difference in the saliva $\mathrm{pH}$ between the younger and older groups was not statistically significant.

Supportive ties to others could have a wide range of positive effects on health (Dickerson \& Zoccola, 2011). Nevertheless, social isolation and loneliness can have detrimental effects. Teacher support was found to be a significant predictor of psychological well-being (Kibret \& Tareke, 2017). Religiosity provides an excellent support network which has been positively associated with well-being (Ngamaba, 2014). The more the clergy feels a sense of well-being in their prayer lives, the lower the burnout scores (Rosetti \& Rhoades, 2013). Having a network of relationships can assist in preventing burnout.

De Campos et al. (2015) found that age, household income, parents' education, saliva flow and pH do not differ among groups. Similarly, Nassar et al., (2014) also found that there is no statistically significant difference in the saliva $\mathrm{pH}$ between the younger and older groups. With regard to age, Mohanraj and Selvaraj (2013) revealed that there is a positive and significant correlation with psychological well-being. According to Rees, Francis and Robbins (2006), age influences the spiritual health and well-being of urban young people.

For young adults, the long-term accumulation of daily stressors in a university setting has been correlated with negative psychological and physiological effects. Contrary to the present investigation, Afrisham (2016) found a significant reduction of salivary IgA levels during exam stress conditions. According to Kibret and Tareke (2017), there is no significant relationship between year (batch) of students and psychological well-being measures. Additionally, Alorani and Alradaydeh (2017) found no significant differences in the mean scores of spiritual well-being based on students' educational year and specialty. However, according to Ziapour et al. (2017), there is a significant relationship between academic term and field of study and spiritual well-being.

Contact with green space leads to psychological restoration related to attenuation of stress and fatigue (Roe et al., 2013). According to Roe et al. (2013), there is a significant negative relationship between higher green space levels and stress levels. This implies that natural environments are associated with stress reduction. Nepomuceno et al. (2015) found significant differences in the psychological well-being between the inhabitants of the rural and urban communities, with a higher average wellbeing score in the rural area. Conversely, Yeresyan and Lohaus (2013) found adolescents who lived in rural areas experience more stress than their urban counterparts. Wissing et al., (2013) also found that the rural group manifests higher levels of well-being on spiritual well-being.

Individuals from more advantaged socioeconomic status (SES) enjoy better mental and physical health than those in the lower SES (Lupie, King, Meaney, \& McEwen, 
2001). According to Kibret and Tareke (2017), income is significantly correlated with almost all the psychological well-being measures. Stein et al. (2013) suggested a direct relationship between perceived economic pressure and psychological well-being such that young adults in financial crisis reported higher levels of depressed mood and anxiety. According to Powell-Young (2012), socioeconomic level and engagement in behaviors that enhance healthy spirituality are the most significant predictors of selfrated health. According to Vahedi and Nazari (2012), there are associations between meaning and purpose in life, religious well-being and life satisfaction.

Family functioning is among the most important factors ensuring the mental health of family members. Dysfunction in family functioning causes many psychological problems for family members (Yahyaee, Nooranipoora, Shafiabadia, \& Farzad, 2015). Davids, Ryan, Yassin, Hendrickse, and Roman (2016) suggested that intact families predict higher satisfaction of basic psychological needs among adolescents than do nonintact families. Akwei (2015) revealed that adolescents from a functional family have higher psychological well-being and that parental conflict and adolescent psychological wellbeing are negatively correlated. Petts (2014) showed that parental interaction and religious services attendance with parent/s in late childhood are associated with higher psychological well-being; whereas, parental conflict in a nontraditional family is associated with lower well-being among youth. Finally, Azuka-Obieke (2013) also revealed that children benefit psychologically and academically when both parents play active roles in the home life.

Maternal relationship quality moderated associations between daily hassles and cortisol production (Lucas-Thompson, 2013). However, Wang (2014) discovered that over time there is no association between parental autonomy support and emerging adult depression and anxiety symptoms. Okray (2016) as well found that helicopter parenting makes children more prone to depression in their emerging adulthood period, scars their self-esteem, and makes them more dependent on their families.

Refuting the results of this study, Dickerson and Zoccola (2011) revealed that the presence of close, supportive ties to others could have a wide range of positive effects on health. High levels of social integration and/or social support are associated with positive biological profiles such lower levels of neuroendocrine activity. Likewise, Sunardi (2014) established that relationship with a bishop/superior is associated with an increased level of commitment, which is positively correlated with psychological well-being and religious well-being. Additionally, Okonkwo (2015) found a positive relationship between servant leadership and spiritual well-being.

Psychological and spiritual coping strengthens the relationship between spirituality and well-being, particularly during stress (Awazie et al., 2015) such as meditation, worship, relaxation, selfless service, prosocial behaviors, and exercise to reduce anxiety and depression. Counter to the results of the study, Maryam Mosavi et al. (2015), found no relationship between serum cortisol level in morning and spiritual well-being scale. On the other hand, Mihaljević, S. et al. (2011) found that there is a significant relationship between spiritual well-being and cortisol levels. Substantiating the results of the study, Fabbris et al. (2016) found a significant negative relationship between anxiety and spiritual well-being, and Unterrainer et al. (2012) also found a 
positive relationship between religiosity/spirituality and subjective well-being and personality dimensions.

The goals of pastoral counseling are spiritual growth, problem resolution, and restoration of psychological health (Sperry, 2016). Specifically, strategic pastoral counseling follows the tenets of cognitive behavioral therapy which involves the exploration of the person's feeling, thoughts, and behavioral patterns for better coping or change. The results of the study are consistent with the studies conducted by Muse et al. (2016) and Aboulafia-Brakha et al. (2014). According to Muse et al. (2016), a weeklong multi-therapist intensive outpatient intervention significantly improves depression, emotional exhaustion, and depersonalization of clergy suffering from depression and burnout. Similarly, Aboulafia-Brakha et al. (2014) found there were significantly lower salivary cortisol levels of caregivers who received cognitive-behavioral group therapy compared to a psychoeducation group program.

\subsection{Conclusion}

These seminarians are emerging adult males undergoing training in preparation for the Catholic priestly ministry. For any emerging adult between the ages of 18 to 25 years old, it is a time when mental health issues emerge due to biology and changing lifestyles. Anxiety and depression are two of the most common mental health issues for the emerging adult in school. The saliva $\mathrm{pH}$ is a good indicator in quantifying the psychological well-being of the seminarians. The Psychological General Well-Being Index (PGWBI) is a good instrument in identifying the psychological well-being, and the Spiritual Well-Being Questionnaire (SWBQ) is a good instrument in identifying the spiritual well-being of the seminarians. When used together, the saliva $\mathrm{pH}$, the PGWBI, and the SWBQ indicate the psycho-spiritual well-being of the seminarians as well as the physiological effects of depression and anxiety.

Emerging adulthood issues continue to include cognitive development, identity formation, ethnic identity, psychological disorders, resilience, family relationships, friendships and romance, sexuality, education, employment, and media use. Nevertheless, it is important to differentiate among adolescence, emerging adulthood, and young adulthood and to more closely study the issues that are unique to those periods.

Spiritual experience and religious beliefs can help in coping with stress and other psychological problems. Spiritual well-being has a protective effect against stress, which leads to a physically and psychologically healthy life, with purpose, meaning, and hope.

Strategic pastoral counseling is an effective program for the improvement and sustainability of the psycho-spiritual well-being of the seminarians.

Seminarians aim for an integral formation in the seminary. Therefore, pastoral counseling should be an important component in this integral formation. Parents should be aware of their psychological and spiritual well-being and find ways to support them fully.

The bishops of the Dioceses of Negros Occidental should make pastoral counseling a part of seminary formation to secure a well-balanced psychological and spiritual well-being of their future vicars. Likewise, seminary formators should welcome 
pastoral counseling as an aid in forming psychologically and spiritually balanced future priests. Additionally, as inspiration for young men to enter the seminary, priests should become more prepared to take an active role not only as co-formators but also as counselors when they are called by their bishops.

Mental health professionals need to incorporate pastoral counseling in counseling and psychotherapy in order to address the holistic development of seminarians.

The Catholic lay faithful should be informed on the psychological and spiritual needs of the seminarians to be more understanding of their struggles and sacrifices to become future priests and to look for venues where they can be of help.

This research serves as a benchmark for future researches on the psychological and spiritual well-being of seminarians belonging to religious orders. Thus, it is recommended that a protocol be developed on the delivery of pastoral counseling specific to the identified needs of the seminarians.

\section{REFERENCES}

Aboulafia-Brakha, T., Suchecki, D., Gouveia-Paulino, F., Nitrini, R., \& Ptak. R. (2014) Cognitive-behavioural group therapy improves a psychophysiological marker of stress in caregivers of patients with Alzheimer's disease. Aging and Mental Health, 18(6), 801-808, DOI: 10.1080/13607863.2014.880406

Adubale, A. A. \& Aluede, O. (2017). A survey of counselling needs of seminarians in Catholic major seminaries in Nigeria. Asia Pacific Journal of Counselling and Psychotherapy. http://dx.doi.org/10.1080/215 07686.2016.1260610

Afrisham, R. (2016). Levels of salivary immunoglobulin A under psychological stress and its relationship with rumination and five personality traits in medical students. The European Journal of Psychiatry, 30(1), 41-53. DOI: http://scielo.isciii.es/scielo.php?script=sci_arttext\&pid=S0213-61632016000100003\&lng=es\&tlng=en.

Akwei, M. (2015). Dysfunctional family, social support and psychological well-being of adolescents in greater Accra. Theses and Dissertations. URI: http://197.255.68.203/handle/123456789/21581

Alorani, O. I. \& Alradaydeh, M. F. (2017). Depression, aggression and spiritual well-being among the university students in Jordan. European Scientific Journal, 13(2), 1857 - 788. URL:http://dx.doi. org/10.19044/esj.2016.v13n2p269

American Psychological Association (APA). (2017). Psychotherapy: Understanding group therapy. Retrieved on November 5, 2017 from http://www.apa.org/helpcenter/group-therapy.aspx

Ardales, V. B. (2008). Basic concepts and methods in research. Manila: Educational Pub. House.

Arnibal, S. P. (2014). Effects of nutritional supplementation on the urine $\mathrm{pH}$ of breast cancer patients. PhD Dissertation, Recoletos de Bacolod Graduate School, University of Negros Occidental - Recoletos, Bacolod City, Philippines

Ashby, J. S. \& Schoon, I. (2012). Living the dream? A qualitative retrospective study exploring the role of adolescent aspirations across the life span. Developmental Psychology, 48(6), 1694-1706. doi:10.1037/ a0027297

Avivor, I. (2009, December 25). The lay faithful in the Roman Catholic Church: A brief historical survey. Retrieved from http://iayivor.weebly.com/ignatius-blog/the-lay-faithful-in-the-roman-catholicchurch-a-brief-historical-survey

Awazie, E., Osarenren, N., \& Nwadinigwe, P. (2015). Impact of cognitive restructuring and pastoral counselling on spiritual wellbeing and role-stress on married people in Umuahia, Abia State, Nigeria. Retrieved on September 1, 2017 from http://www.bjournal.co.uk/volume/paper/BJASS_19_2/ BJASS_19_02_04.pdf

Azuka-Obieke, U. (2013). Single-parenting, psychological well-being and academic performance of adolescents in Lagos, Nigeria. Journal of Emerging Trends in Educational Research and Policy Studies, 4(1), 
112-117. https://pdfs.semanticscholar.org/0dab/606918cbb98723f15548085957588cab56c8.pdf

Bash, A. (2004). Spirituality: The emperor's new clothes? Journal of Clinical Nursing, 13, 11-16. Retrieved on August 11, 2017 from http://www.ncbi.nlm.nih.gov/pubmed/14687288

Benner, D. G. (2003). Strategic pastoral counseling: A short-term structured model (2nd Ed.). Baker Academic.

Bhogaonker, P. (2012). Impact of brief meditation training on stress, distress, and quality of life for homeless adults. Retrieved February 20, 2018, from https://search.proquest.com/openview/c832c86bc4a1a6a40571a92cdf6c104b/1?pq-origsite=gscholar \&cbl=18750\&diss=

Catholic Bishops' Conference of the Philippines (CBCP). (2006). The Updated Philippine Program of Priestly Formation. Catholic Bishops' Conference of the Philippines Episcopal Commission on Seminaries. Manila, Philippines

Cooper-White, P. (2004). What is Pastoral Counseling? Retrieved on September 11, 2017 from http://www. pastoral-counselling.co.uk/pastoralcounselling.html

Davids, E. L., Ryan, J., Yassin, Z., Hendrickse, S., \& Roman, N.V. (2016). Family structure and functioning: Influences on adolescents psychological needs, goals and aspirations in a South African setting [Abstract]. Journal of Psychology in Africa, 26(4), 351-356. DOI: 10.1080/14330237.2016.1208929

Dayringer, R. (2012). The image of God in pastoral counseling. Journal of Religion and Health, 51(1), 49-56. doi:http://0-dx.doi.org.lib1000.dlsu.edu.ph/10.1007/s10943-011-9536-y

De Campos, M. M., Yukie Kobayashi, F., Barbosa, T., da Silva Costa, S., Lucas, B., \& Castelo, P. (2015). Characteristics of salivary secretion in normal-weight, overweight and obese children: A preliminary study [Abstract]. Odontology, 102(2), 318. https://link.springer.com/article/10.1007/s10266-0130103-8

Dickerson, S. S. \& Zoccola, P. M. (2011). Toward a biology of social support. In: Snyder, C. R. \& Lopez, S. J. (eds) The Oxford Handbook of Positive Psychology (2e). Oxford University Press Inc. New York.

Duc Dao, J. D. (2015). The formation of seminarians in the Vietnamese context according to the teachings of the Catholic Church. Priestly Formation in the Asian Context, Special Issue. Retrieved on August 13, 2017 from http://stt.catholic.ac.kr/DATA/STTBOOK/1436491614247.pdf

Dupuy, H. (2002). Scaling and scoring of the Psychological General Well-Being Index (PGWBI). MAPI Research Trust. France.

Ebrahimisani E., Hashemian K. \& Dvkanha F. (2012). The effectiveness of transactional analysis group therapy in increasing the self-esteem of Northern Khorasan Province Prisons' soldier-guards. Retrieved on September 2, 2017 from http://militarymedj.ir/article-1-968-en.pdf

Etengoff, C. \& Daiute, C. (2013). Sunni-Muslim American religious development during emerging adulthood. Journal of Adolescent Research, 28(16), 690-714. https://doi.org/10.1177/0743558413477197

Fabbris, J. L., Mesquita, A. C., Caldeira. S., Carvalho, A. M., \& Carvalho, E. C. (2016). Anxiety and spiritual well-being in nursing students: A cross-sectional study [Abstrct]. Journal of Holistic Nursing, 35(3), 261-270. https://doi.org/10.1177/0898010116655004

Gañon, P., Ondap, C., Panganiban, J. J. L., Tangan, J. B., Carlo Enrico C. Tinio, C. E. C., \& Tony Yap, T. (2008). Resilience of seminarians sent out of seminary formation. Loyola School of Theology. Ateneo de Manila, Philippines.

Gayoles, L. A. M. (2005). The effect of high intensity aerobic exercise on the stress level and pain threshold of college teachers. MA Education concentration on Psychology and Guidance Thesis, Graduate School, STI-West Negros University (formerly West Negros College), Bacolod City, Philippines

Gayoles, L. A. M. (2010). The effect of supportive counseling on the anxiety level of preoperative breast cancer patients. PhD Psychology Dissertation, Graduate School, University of San Agustin, Iloilo City, Philippines

Gomez, R. \& Fisher, J. (2003). Domains of spiritual well-being and development and validation of the Spiritual Well-Being Questionnaire. Personality and Individual Differences. 35, 1975-1991. doi:10.1016/ S0191-8869(03)00045-X

Holder, M. D., Coleman, B., \& Wallace, J. M. (2010). Spirituality, religiousness, and happiness in children aged $8-12$ years. In Journal of Happiness Studies, 11(2), 131-150. https://doi.org/10.1007/s10902008-9126-1 
Huppert, F. A. (2009). Psychological well-being: Evidence regarding its causes and consequences. Applied Psychology: Health And Well-Being, 1(2), 137-164. doi:10.1111/j.1758-0854.2009.01008

Jafari, N., Farajzadegan, Z., Zamani, A., Bahrami, F., Emami, H., Loghmani, A., \& Jafari, N. (2013). Spiritual therapy to improve the spiritual well-being of Iranian women with breast cancer: A randomized controlled trial. Evidence-Based Complementary and Alternative Medicine, 2013 (353262). doi:10.1155/2013/353262

Johnson, V. K. \& Gans, S. E. (2016). Parent cortisol and family relatedness predict anxious behavior in emerging adults [Abstract]. Journal of Family Psychology, 30(7), 802-811. http://dx.doi.org/10.1037/ fam0000236

Karner, B. A. (2013). Easy effective counseling: A strategy for busy pastors (Order No. 3558324). Available from ProQuest Dissertations \& Theses A\&I; ProQuest Dissertations Theses Global. (1348976113). Retrieved on August 13, 2017 from http://0-search.proquest.com.lib1000.dlsu.edu.ph/ docview/1348976113?accountid=28547

Keating, D. J. (2010). Priestly formation as spirituality. Retrieved on August 13, 2017 from www.clerus.org/ clerus/dati/2009.../Priestly_formation_as_spirituality_en

Kehe, J. V. (1997). The pastoral counselor in the 90's: From a ministry of the ordained to a ministry of the baptized (Order No. 9805225). Available from ProQuest Dissertations \& Theses A\&I; ProQuest Dissertations \& Theses Global. (304412713). Retrieved on September 2, 2017 from http://0-search. proquest.com.lib1000.dlsu.edu.ph/docview/304412713 accountid $=28547$

Kibret, B. T. \& Tareke, G. (2017). The contribution of instructor, peer and university support for promoting psychological well-being among students in the Amhara Regional universities. Clinical and Experimental Psychology, 3(2). DOI: 10.4172/2471-2701.1000154

Knight, K. (2012). Ecclesiastical seminary. New Advent. Catholic Encyclopedia. Retrieved on September 17, 2017 from http://www.newadvent.org/cathen/13694a.htm

Lucas-Thompson, R. G. (2013). Relationship quality with parents, stressful life events, and cortisol production in emerging adulthood. Emerging Adulthood, 2(2), 92 - 104. https://doi. org/10.1177/2167696813503313

Lupie, S. J., King, S., Meaney, M. S. \& McEwen, B. S. (2001). Can poverty get under your skin? Basal cortisol levels and cognitive function in children from low and high socioeconomic status. In: Hyman, S. E. (ed) The Science of Mental Health: Stress and the Brain. Routledge, New York

Manning-Walsh, J. K. (2005). Psychospiritual well-being and symptom distress in women with breast cancer. Oncology Nursing Forum, 32(3). DOI: 10.1188/05.ONF.E56-E62

Maryam Mosavi, S., Pourmarzi, D., Dehganzadeh, S., Ruzbehan, B., \& Pourhamed, G. (2015). Relationship between spiritual well-being and cortisol level in nursing students [Abstract]. Pajoohandeh Journal, 20,12-17. https://www.researchgate.net/publication/281522618_Relationship_between_spiritual_well-being_and_cortisol_level_in_nursing_students

McShane, C. R. (2015). Psychological attachment issues in catholic seminarians: Concepts and interview data relevant for formators and psychologists (Order No. 3704280). Available from ProQuest Dissertations \& Theses A\&I; ProQuest Dissertations \& Theses Global. (1690497558). Retrieved on August 19, 2017 from http://0-search.proquest.com.lib1000.dlsu.edu.ph/docview/1690497558?accountid $=28547$

Mihaljević, S., Vuksan-Ćusa, B., Marčinko, D., Koić, E., Kušević, Z., \& Jakovljević, M. (2011). Spiritual well-being, cortisol, and suicidality in Croatian war veterans suffering from PTSD [Abstract]. Journal of Religion and Health, 50(2), 464-73. doi: 10.1007/s10943-010-9383-2

Mohanraj, B. \& Selvaraj, I. (2013). Psychological issues among hearing impaired adolescents. GESJ: Education Science and Psychology, 2(24)

Moodley, T. (2008). The relationship between coping and spiritual well-being during adolescence. PhD in Child Psychology Thesis, Department of Psychology, University of the Free State, Bloemfontein, South Africa

Muse, S., Love, M. \& Christensen, K. J. (2016). Intensive outpatient therapy for clergy burnout: How much difference can a week make? [Abstract]. Journal of Health and Religion, 55(1). DOI: https://doi. org/10.1007/s10943-015-0013-x 
Nassar, M., Hiraishi, N., Islam, S., Otsuki, M., \& Tagami, J. (2014). Age-related changes in salivary biomarkers [Abstract]. Journal of Dental Sciences, 9(1), 85-90. DOI: https://doi.org/10.1016/j.jds.2013.11.002

Nepomuceno, B. B., Cardoso, A. A. V., Ximenes, V. M., Barros, J. P. P., \& Leite, J. F. (2015). Mental health, well-being, and poverty: A study in urban and rural communities in Northeastern Brazil. Journal of Prevention and Intervention in the Community, 44(1), 63-75. DOI: 10.1080/10852352.2016.1102590

Ngamaba, K. H. (2014). Religious leaders' perceptions of their emotional and psychological needs. Mental Health, Religion \& Culture, 17(1), 62-78, http://dx.doi.org/10.1080/13674676.2012.746654

O'Connell, Gerard. (2014). Rough Diamonds. America, The National Catholic Review. Retrieved on September 24, 2017 from http://americamagazine.org/issue/rough-diamonds\%E2\%80\%99

Odle, T. \& Mayer, R. (2009). Experimental research. Retrieved on August 13, 2017 from http://www.education.com/reference/article/experimental-research/

Okonkwo, J. C. (2015). The effects of servant leadership on the socio-moral climate of catholic parishes and the spiritual well-being of followers. Dissertation. https://hdl.handle.net/11244/15532

Okray, Z. (2016). Helicopter parenting and related issues: Psychological well being, basic psychological needs and depression on university students. Current Research in Education, 2(3), 165-173. Retrieved February 19, 2018, from http://www.toad.edam.com.tr/sites/default/files/pdf/helikopter-anne-babalik-olcegi-toad.pdf

Petts, R. J. (2014). Family, religious attendance, and trajectories of psychological well-being among youth [Abstarct]. Journal of Family Psychology, 28(6), 759-768. http://psycnet.apa.org/buy/2014-18280001

Powell-Young, Y. M. (2012). Household income and spiritual well-being but not body mass index as determinants of poor self-rated health among African American adolescents [Abstract]. Research in Nursing and Health, 35(3), 219-230. DOI: 10.1002/nur.21473

Pring, R. (2014). A world set apart: Seminary life before Vatican II, a study in cultural anthropology. International Studies in Catholic Education, 6(2), 201-208. http://dx.doi.org/10.1080/19422539.2014.92 9809

Rees, G., Francis, L. J., \& Robbins, M. (2006). Spiritual health and the well-being of urban young people. The Children's Society. London

Reifman, A., Arnett, J. J., \& Colwell. M. J. (2007). Emerging adulthood: Theory, assessment and application. Journal of Youth Development: Bridging Research and Practice, 2(1), Article 0701FA003. Retrieved on November 2, 2017 from https://jyd.pitt.edu/ojs/jyd/article/download/359/345

Roe, J. J., Thompson, C. W., Aspinall, P. A., Brewer, M. J., Duff, E. I., Miller, D., ... Clow, A. (2013). Green Space and Stress: Evidence from Cortisol Measures in Deprived Urban Communities. International Journal of Environmental Research and Public Health, 10(9), 4086-4103. http://doi.org/10.3390/ ijerph10094086

Rossetti, S. J. \& Rhoades, C. J. (2013). Burnout in Catholic clergy: A predictive model using psychological and spiritual variables. Psychology of Religion and Spirituality, 5(4), 335-341. doi:10.1037/a0033639

Society of Counseling Psychology, Division 17, American Psychological Association. (2017). What is counseling psychology. Retrieved on October 2, 2017 from http://www.div17.org/about-cp/what-is-counseling-psychology/

Sperry, L. (2016). Varieties of religious and spiritual treatment: Spirituality oriented psychotherapy and beyond. Spirituality In Clinical Practice, 3(1), 1-4. doi:10.1037/scp0000097

Stanosz, P. (2004). Reproducing celibacy: A case study in diocesan seminary formation. ETD Collection for Fordham University. Paper AAI3140903. Retrieved on September 6, 2017 from http://fordham. bepress.com/dissertations/AAl3140903

Stawski, R. S., Cichy, K. E., Piazza, J. R., \& Almeida, D. M. (2013). Associations among Daily Stressors and Salivary Cortisol: Findings from the National Study of Daily Experiences. Psychoneuroendocrinology, 38(11), 2654-2665. http://doi.org/10.1016/j.psyneuen.2013.06.023

Steen, S., Henfield, M. S., \& Booker, B. (2014). The achieving success everyday group counseling model: Implications for professional school counselors. The Journal for Specialists in Group Work. http://dx.doi. org/10.1080/01933922.2013.861886 
Stein, C., Hoffmann, E., Bonar, E., Leith, J., Abraham, K., Hamill, A., ... , Fogo, W. (2013). The United States economic crisis: Young adults' reports of economic pressures, financial and religious coping and psychological well-being. Journal of Family and Economic Issues, 34(2), 200-210. DOI https://doi. org/10.1007/s10834-012-9328-x

Streets, F. J. (2014). Love: A philosophy of pastoral care and counselling. Verbum Et Ecclesia, 35(2), 1-11. Retrieved on September 1, 2017 from http://0-search.proquest.com.lib1000.dlsu.edu.ph/ docview/1636192200?accountid=28547

Sunardi, Y. (2014). Predictive factors for commitment to the priestly vocation: A study of priests and seminarians (Order No. 3646926). Available from ProQuest Dissertations \& Theses A\&l; ProQuest Dissertations \& Theses Global. (1637726973). Retrieved on September 5, 2017 from http://0-search. proquest.com.lib1000.dlsu.edu.ph/docview/1637726973?accountid=28547

Thompson, C. W. et al. (2012). More green space is linked to less stress in deprived communities: Evidence from salivary cortisol patterns. Landscape and Urban Planning, 105(3), 221-229. https://doi. org/10.1016/j.landurbplan.2011.12.015

Thompson, R. (2014). Stress and child development. The Future of Children, 24(1), 41-59. Retrieved on September 18, 2017 from http://0-www.jstor.org.lib1000.dlsu.edu.ph/stable/23723382

Trible, H. (2015). Emerging adulthood: Defining the life stage and its developmental tasks. Educational Specialist Thesis, Graduate Psychology, James Madison University. Retrieved on November 2, 2017 from http://commons.lib.jmu.edu/cgi/viewcontent.cgi?article=1007\&context=edspec201019

Unterrainer, H. F., Lewis, A. J., \& Fink, A. (2012). Religious/spiritual well-being, personality and mental health: A review of results and conceptual issues [Abstract]. Journal of Religion and Health, 53(2), 382392. DOI https://doi.org/10.1007/s10943-012-9642-5

Vahedi, S. \& Nazari, M. A. (2012) The relationship between self-alienation, spiritual well-being, economic situation and satisfaction of life: A Structural equation modeling approach. Iranian Journal of Psychiatry and Behavioral Sciences (IJPBS), 5(1), 64-73. URL: http://ijpbs.mazums.ac.ir/article-1-68en.html

Van Gaasbeck, J., Panthee, J., Owens, C., Malla, R., Edelman, S., \& DelFerro, J. (2017). Sleep, perceived stress, and salivary cortisol response in undergraduate students. Journal of Undergraduate Research (JOURney), 1, 42-49. University of Northern Carolina. Retrieved on February 25, 2018 from https:// uncjourney.unc.edu/files/2017/05/JOURneySpring2017vol1Digital-1.pdf

Wang, J. C. (2014). Parental autonomy support and emerging adult anxiety and depression: Determining direction of effects. Retrieved February 19, 2018, from https://scholarsbank.uoregon.edu/ xmlui/bitstream/handle/1794/18502/Wang_oregon_0171A_11084.pdf?sequence=1\&isAllowed=y

Wiggins, V. R. (2014). Mother and adult daughter relationships and the impact on emotional health, self-efficacy, and spiritual well-being. Retrieved February 19, 2018, from https://search.proquest.com/ openview/29090578f69ce9cf61a17f33e7a4b35e/1?pq-origsite=gscholar \&cbl=18750\&diss=y

Wissing, M. P., Temane, Q. M., Khumalo, I. P., Kruger, A., \& Vorster, H. H. (2013). In: Wissing, M. P. (ed) Well-Being Research in South Africa. Springer Science \& Business Media. New York

Yahyaee, G. A., Nooranipoora, R., Shafiabadia, A., \& Farzad V. (2015). The effectiveness of transactional analysis group-counseling on the improvement of couples' family functioning. Retrieved on September 2, 2017 from http://jhygiene.muq.ac.ir/article-1-42-en.pdf

Yeager, D. (2017). Social and emotional learning programs for adolescents. The Future of Children, 27(1), 73-94. Retrieved on August 16, 2017 from http://0-www.jstor.org.lib1000.dlsu.edu.ph/stable/ pdf/44219022. pdf?refreqid=search\%3Aec477bcec9472d179b9199a591938a55

Yeresyan, I. \& Lohaus, A. (2013). Stress and wellbeing among Turkish and German adolescents living in rural and urban areas. Rural and Remote Health, 14(1), 2695. DOI:www.rrh.org.au/journal/article/2695

Ziapour, A., Khatony, A., Jafari, F., \& Kianipour, N. (2017). Prediction of the Dimensions of the Spiritual Well-Being of Students at Kermanshah University of Medical Sciences, Iran: The Roles of Demographic Variables. Journal of Clinical and Diagnostic Research, 11(7), VC05-VC09. doi: 10.7860/ JCDR/2017/25114.10314 